\title{
Volunteering for a Lifetime? Volunteers' Intention to Stay in Portuguese Hospitals
}

\author{
Marisa R. Ferreira • Teresa Proença • \\ João F. Proença
}

(C) International Society for Third-Sector Research and The Johns Hopkins University 2014

\begin{abstract}
The current study aims to study Hospital volunteers' intention to stay in an organization through understanding motivation, management factors, and satisfaction. A total of 304 Hospital volunteers, mainly women, completed a questionnaire measuring motivations, management factors, satisfaction, and intention to stay. In this study, structural equation modeling was used. Results demonstrate that there is a positive relationship between (a) motivation and satisfaction, (b) management factors and satisfaction, (c) satisfaction and intention to stay, and (d) motivation and management factors. These results present important outcomes that should be reflected in the way organizations operate. This research indicates aspects which are most valued by volunteers and allows NPOs to design and establish appropriate and assertive management policies.
\end{abstract}

Résumé La présente étude vise à examiner l'intention des hospitaliers bénévoles de rester dans une organisation, au travers de leur motivation, de leur satisfaction et de facteurs de gestion. Au total, 304 hospitaliers bénévoles (principalement des femmes) ont rempli un questionnaire mesurant les motivations, la satisfaction, les facteurs de gestion et l'intention de rester. Pour les besoins de cette étude, nous avons fait appel à une modélisation par équations structurelles. Les résultats montrent une corrélation positive entre (a) la motivation et la satisfaction; (b) les facteurs de gestion et la satisfaction; (c) la satisfaction et l'intention de rester; et (d) la motivation et les facteurs de gestion. Ces résultats ont d'importantes conséquences qui devraient influencer la manière dont fonctionnent les organisations. Cette étude indique les aspects que les bénévoles considèrent comme les plus

\footnotetext{
M. R. Ferreira $(\bowtie)$

School of Management and Technology of Felgueiras, CIICESI, Porto PolytechnicInstitute, Rua do Curral - Casa do Curral, 4610-156 Margaride, Felgueiras, Portugal

e-mail: marisaferreira@eu.ipp.pt

T. Proença · J. F. Proença

Faculty of Economics, University of Porto, Rua Dr. Roberto Frias, Porto, Portugal
} 
importants; les associations à but non lucratif pourront ainsi concevoir et établir des politiques de gestion adéquates et assertives.

Zusammenfassung Ziel der vorliegenden Studie ist es, die Absicht ehrenamtlicher Krankenhausmitarbeiter, längerfristig für eine Organisation tätig zu sein, zu untersuchen, indem näher auf die Aspekte Motivation, Managementfaktoren und Zufriedenheit eingegangen wird. Insgesamt 304 ehrenamtliche Krankenhausmitarbeiter, hauptsächlich Frauen, füllten einen Fragebogen aus, mithilfe dessen die Motivation, Managementfaktoren, Zufriedenheit und die Absicht einer längerfristigen Tätigkeit bewertet wurden. In der Studie wurde das Strukturgleichungsmodell angewandt. Die Ergebnisse zeigen positive Korrelationen zwischen (a) der Motivation und der Zufriedenheit, (b) den Managementfaktoren und der Zufriedenheit, (c) der Zufriedenheit und der Absicht einer längerfristigen Tätigkeit. Diese Ergebnisse präsentieren wichtige Auswirkungen, die sich in der Art und Weise, in der Organisationen operieren, widerspiegeln sollten. Die Studie weist die Aspekte auf, die von ehrenamtlich Tätigen am meisten geschätzt werden und ermöglicht es gemeinnützigen Organisationen, geeignete ausdrückliche Managementgrundsätze zu etablieren.

Resumen El presente estudio tiene como objetivo estudiar la intención de los voluntarios de Hospital de permanecer en una organización mediante la comprensión de la motivación, factores de gestión y satisfacción. Un total de 304 voluntarios de Hospital, principalmente mujeres, completaron un cuestionario que medía la motivaciones, los factores de gestión, la satisfacción y la intención de seguir. En el presente estudio, se utilizó el modelo de ecuación estructural. Los resultados demuestran que existe una relación positiva entre (a) la motivación y la satisfacción, (b) los factores de gestión y la satisfacción, (c) la satisfacción y la intención de quedarse y (d) la motivación y los factores de gestión. Estos resultados presentan importantes conclusiones que deben ser reflejadas en la forma en la que operan las organizaciones. La presente investigación indica los aspectos que son más valorados por los voluntarios y permite a las organizaciones sin ánimo de lucro (OSAL/NPO) diseñar y establecer políticas de gestión apropiadas y enérgicas.

Keywords Motivation - Satisfaction - Management factors · Intent to stay · Hospital volunteers

\section{Introduction}

Volunteering is a phenomenon with a substantial level of maturity (Schervish 1993) has, over time, occupied space, and people (Pedro 2010) and has become a critical human resource for many organizations (Karl et al. 2008). The development of NPOs gives evidence to this, although this has not been accompanied by an equal growth in terms of available resources (Randle and Dolnicar 2009). Management practices used in paid work are not always appropriate in volunteer work because there are important differences between volunteers and employees (Ferreira et al. 
2008), and sometimes NPOs are less clear about the meaning of management. Previous to the 1980s, interest in management practices within the volunteer sector was marginal, although nowadays NPOs development stresses the need for guidelines with professional and skilled instructions on how to successfully manage organizations (Drucker 1990). At the same time, the demand for volunteers often exceeds the supply, so volunteers can be selective about where they choose to apply their time (Hager and Brudney 2011; Hartenian 2007).

Our research is placed adjacently to the applications of human resource management (HRM) in nonprofit organizations. In general terms, managing resourceful humans involves a continuous balancing between meeting the human aspirations of the people and meeting the strategic and financial requests of the organization (Torrington et al. 2002). Although, among human resource research of business and nonprofit organizations, there are important dissimilarities, including differences in values, mission, identity, social goals, outcomes, and ideological characteristics (Ridder and McCandless 2010). Some researches state that strategic HRM is largely absent from nonprofit organizations (Akingbola 2006; Hager and Brudney 2011; Pynes 2009). Many NPOs are confronted with the need to manage people who work there, theoretically organizations recognize the importance of HRM, but in practice HRM as management practice is undeveloped and the formal adoption of procedures is achieved slowly (Gomes 2009). HRM has not tended to take the nonprofit case into account (Taylor et al. 2006), but the same authors consider that there is essential to add knowledge to the conceptualization of volunteer management practices using an HRM framework. At the same time, given the economic and societal importance of NPOs (Wilson 2000), combined with NPO sector demands for more scientifically based guidelines on volunteer management (Musick and Wilson 2008), it seems essential to extend our knowledge on this subject. Organizations must observe and consider external pressures (e.g., unpredictable life courses) and internal pressures (e.g., increasing pursuit of professionalism and efficiency) restructuring volunteer's behavior (Hustinx and Lammertyn 2003). So, the main objective of this research is to understand volunteers' intentions to stay in an organization. The cost of turnover is enough to penalize an organization and there are many benefits associated with volunteer continuity such as financial, organizational, and cultural aspects (Watson and Abzug 2005). Volunteers' intention to stay has been studied in several areas (Arias 2008; Dávila and Chacón 2002; Hidalgo and Moreno 2009; Millette and Gagné 2008), although there are very few studies in the hospital context (Wymer 1999). Most of the existing research was carried out in organizations related to sport, environment or art (specifically in museums), and this can influence volunteers intention to stay. Therefore, this research will study hospital volunteers, who can be seen as peculiar form of voluntary whose action is based in a hospital context (Byers et al. 1976). Hospitals can be greatly humanized by volunteer activity (Wymer 1999). It is believed that volunteers complement the perceived quality of a hospital by contributing to the happiness and comfort of patients, their families, and visitors since they add a human touch to the technical aspect of care (Hotchkiss et al. 2009). Although hospital volunteers are seen as a great resource to hospitals, there is little empirical evidence to support this view (Hotchkiss et al. 2009; Nogueira-Martins 
et al. 2010). Thus, we theoretically analyze all the variables that influence volunteers' intention to stay; we outline the design of our study to test the hypotheses; we provide the results; and finally we discuss the main implications.

\section{Background}

\section{Motivations}

Motivation is an internal psychological concept (Latham 2007), a basic psychological process or a need that activates a behavior (Luthans 2011), defined as the process that initiates, guides, and maintains goal-oriented behaviors and results from the interaction between an individual and the environment (Latham and Pinder 2005). The literature underlines the importance of understanding volunteers' motivations in order to allow organizations to meet volunteers' expectations (Qureshi et al. 1979). Identifying the key motives of individual volunteers is fundamental (Bussell and Forbes 2002), and fortunately there has been substantial research investigating and examining volunteers motivations (Bussell and Forbes 2002; Clary et al. 1998; Smith and Schneider 2004; Wymer 1999).

The distinction between altruistic and egoistic motivations (Horton-Smith 1981; Phillips 1982) or other non-altruistic reasons (Frisch and Gerrard 1981; Henderson 1981) are reasonably deep-rooted. In fact, altruism has long been identified as a primary motivation by many authors (Esmond and Dunlop 2004; Howarth 1976; Tapp and Spanier 1973), and according to Monroe (1996) it can be considered as an incentive that will benefit others, even when this means a sacrifice for the welfare of the actor. Numerous authors identify altruistic and non-altruistic motivations as the concern of the individual with others and the self (Phillips 1982), career concerns (Frisch and Gerrard 1981), or leisure (Henderson 1981). The multifactor model divides motivations according to their functions and classifies motivations as value, understanding, social, protective, and enhancement (Clary et al. 1998). Other researchers have classified volunteer motivations into intrinsic and extrinsic motivations (Handy and Srinivasan 2004; Meier and Stutzer 2004; Raman and Pashupati 2002; Ryan and Deci 2000). Intrinsic motivation is a result of personal enjoyment, interest, or pleasure and does not expect any material reward (Ryan and Deci 2000), whereas extrinsic motivations are ruled by contingencies, meaning that instrumental reasons are essential and external benefits are expected (Meier and Stutzer 2004). Ferreira et al. (2012) identified four different motivation categories: development and learning, altruism, career recognition, belonging, and protection. The first category, development and learning, includes motivations related to the learning process and the opportunity for new experiences, the expansion of horizons (Trogdon 2005), and the rise of experiences. Altruism includes motives related to "helping others" (Cavalier 2006) or the purpose of "making something worthwhile" (Soupourmas and Ironmonger 2001). The third category, belonging and protection, includes motivations associated with social interaction, friendship, affection and love (Latham 2007), making new friends, meeting people (Hibbert et al. 2003), and relationship network (Edwards 2005). The least important category 
is related to career recognition, which means that volunteers are not motivated by issues related to their career. In this category are the aims of making business contacts and improving a CV/résumé in order to increase employability and gain experience beneficial to full time work (Rhoden et al. 2009).

\section{Management Factors}

Organizations can no longer afford to treat volunteers as amateurs, but need to offer them skills to the point that they emerge as trained, professional, unpaid members of staff (Cunningham 1999). According to Vantilborgh et al. (2011), NPOs are becoming more professionalized and in recent decades there have been a wide range of articles analyzing the developments of NPOs (Anderson and Cairncross 2005; Chater 2008; Cnaan and Cascio 1998; Cunningham 1999; Cuskelly and Auld 2000a, b; Cuskelly et al. 2006; Dartington 1991; Willis 1991). It is important to note that professionalization introduces negative and positive effects. In terms of benefits, it provides NPOs with more consistent resources, greater efficiency and innovation, better targeting of services to customer/user requirements, and improved accountability (Eikenberry and Kluver 2004). However, there is a lack of empirical evidence in many of the cited consequences and the effects of professionalization remains unexplored in many cases (Vantilborgh et al. 2011).

Some authors (Ferreira et al. 2012) have identified the most important management factors that can influence volunteer work to be recruitment and selection, training, and rewards. Volunteers with appropriate expertise or qualifications can provide suitable skills (Warner et al. 2011), so recruitment is very important to an organization's survival and growth (Brudney and Kellough 2000).

The recruitment process is a primary task for NPOs (Hager and Brudney 2011), yet it is frequently an informal process. Attracting qualified applicants can be a complex task (Cuskelly and Auld 2000b) since this process should not be a search for manpower unrelated to qualifications, but a selective mission to locate and attract citizens with appropriate backgrounds and aspirations to fill organizational needs (Brudney 1990; Edwards 2005). At the same time, organizations compete for these scarce resources (i.e., volunteers) and face the additional challenge of recruiting volunteers in a highly competitive marketplace (Warner et al. 2011). "Training is the process of instructing volunteers in the specific job-related skills and behavior that they will need to perform in their particular volunteer job" (McCurley 2005, p. 606). Training is costly and time-consuming and sometimes organizations think that investing in training is not worthwhile (Hartenian 2007). Nevertheless, the lack of suitable training is seen as a significant constraint on the success of the voluntary sector (Amos-Wilson 1996; Cunningham 1999). Several organizations consider volunteer training as essential, however, this import is not regularly conveyed and often is considered unnecessary (Nunes et al. 2001). Many volunteers need to know that they are appreciated, they make a difference, and the sensation of being recognized and esteemed is a significant factor that volunteers value (Cnaan and Cascio 1998). Some volunteers give importance to more formal recognition (Brudney 1990) such as dinners, gifts, certificates, plaques, trophies, or reference letters (Brudney and Nezhina 2005; Brudney 2005). The use of symbolic 
rewards and recognition activities might be significant in explaining volunteer satisfaction (Farrell et al. 1998), hours volunteered per month (commitment), length of service (tenure) (Cnaan and Cascio 1998), and retention (Hager and Brudney 2004).

\section{Satisfaction}

Job satisfaction can be defined as "a pleasurable or positive emotional state resulting from an appraisal of one's job or job experiences" (Locke 1976, p. 1304). Although the literature about workers behavior is vast, it cannot be extended and overlaid to volunteers because there are relevant distinctions between workers and volunteers (Ferreira et al. 2008). These distinctions can affect individuals' attitudes regarding the tasks they are assigned to, and at the same time influence their job satisfaction (Galindo-Kuhn and Guzley 2001). Satisfaction is a challenging concept to study, since it has a wide range of interpretations (Vecina et al. 2010) and the majority of the research on volunteerism agrees with the idea that job satisfaction plays an important role in volunteer behavior (Hibbert et al. 2003), although there is not unanimity about the dimensions that should be considered (Vecina et al. 2010). The variety of tools used to measure job satisfaction in a business context helps us to understand the complexity and diversity of the conceptualizations of this construct (Silverberg et al. 2001). It seems logical to think that more satisfied volunteers will be more dynamic and that the probability of staying in the same organization is higher (Finkelstein 2008). In order to better recruit, train, and retain volunteers, there is a need to identify ways to increase the overall satisfaction of volunteers with their experience and work (Costa et al. 2006), thus volunteer managers must determine how to provide this satisfaction and work toward volunteer retention (Warner et al. 2011).

Some authors found a positive relationship between some types of motivations and volunteers satisfaction (Kemp 2002; Omoto and Snyder 1995; Silverberg et al. 2001; Vecina et al. 2010) meaning that volunteers that present higher levels of satisfaction are those whose activities allow them to meet their main motivations. Satisfaction is extremely important for organizations that rely on volunteer work, however, according to (Silverberg et al. 2001), there are very few studies in this area. Based on the evidence mentioned above, we assume that:

Hypothesis There is a positive relationship between volunteer motivation and satisfaction.

Management factors can play a very important role in the daily lives of volunteers, as well as in their satisfaction and intention to stay. Literature on volunteers' organizational behavior and on their performance is scarce (Cnaan and Cascio 1998). Furthermore, it is important to improve the knowledge of volunteer management practices (Stamer et al. 2008) and create organizational structures to promote volunteerism allowing an adequate management (Paúl et al. 1999). Therefore, we intend to understand the impact of management factors on volunteers' satisfaction and intention to stay. Based on the evidence mentioned above, we assume that: 
Hypothesis There is a positive relationship between management factors (recruitment and selection, training, and recognition/reward) and volunteer satisfaction.

\section{Intention to Stay}

Volunteer intent to stay is the probability, identified by themselves, of remaining as volunteers in a certain organization (Dávila and Chacón 2002). Closely related to this, we have the intention to leave and turnover. "Intention to leave is considered a conscious and deliberate desire to leave an organization within the near future" (Cho et al. 2009, p. 374) and turnover is the rotation of the number of volunteers (Federman 2009). With fewer people volunteering and the increased request for volunteer support, retaining motivated and skilled volunteers is absolutely essential (Warner et al. 2011). Effective retention reduces the need for recruitment (Starnes and Wymer 2001) but requires careful attention to all phases of the volunteer experience (Karl et al. 2008). Evidence shows that using a new volunteer is much more expensive than investing in an existing one, so it is fundamental for an organization to develop an internal plan focused on increasing volunteers' commitment and long-term retention (Karl et al. 2008).

Identifying the specific factors that affect the decision to stay may be extremely fruitful for an organization and many theoretical models have been developed to try to explain these factors. Reasons related to altruism, personal development, concern for the community, and self-esteem are identified as important motivational factors related to the intention to stay (Omoto and Snyder 1993). The influence of demographic variables (e.g., age, marital status, income, or education) are important (Chacón et al. 2007; Cnaan and Cascio 1998; Hidalgo and Moreno 2009; Huber 2011; Kulik 2007; Omoto and Snyder 1995) as well as the volunteer's role in an organization, their satisfaction (Cheung et al. 2006) and the influence of the organization management (Ferreira et al. 2012; Huber 2011). Finally, it is important to mention that "research in the area of volunteer retention is sparse and somewhat inconclusive" (McBride and Lee 2012, p. 346). So, it can be argued that the most motivated individuals are those who intend to stay (Vecina et al. 2010), meaning that volunteers intention to stay may be dependent on whether an organization can meet their motivations or not (Vecina et al. 2010). Based on the evidence mentioned above, we assume that:

Hypothesis There is a positive relationship between volunteer motivation and intention to stay.

Literature presents some researches on volunteers' satisfaction, but understanding its connection with the management factors and volunteers intention to stay still not very explored. The impact of management factors (recruitment and selection, training, reward, and recognition) in volunteers satisfaction and intention to stay have been studied in an isolated format (Cuskelly and Auld 2000b; Lulewicz 1995; Peach and Murrell 1995) and there are few studies that analyze, conjointly, management factors role (Cuskelly et al. 2006; Dávila and Chacón 2002; McCurley 2005) to understand their influence on satisfaction (Costa et al. 2006) and the 
intention to stay (Arias 2008; Cuskelly et al. 2006). Based on the evidence mentioned above, we assume that:

Hypothesis There is a positive relationship between management factors (recruitment and selection, training and recognition/reward) and volunteers' intention to stay.

"Dissatisfied workers are more likely to leave their job than satisfied workers. Thus, satisfaction levels can give us some information about individual intentions" (Bilhim 2006, p. 336). Turnover can be extremely volatile, however, organizations consider essential to have more control over this variable (Federman 2009). The evidence suggests that when a volunteer is satisfied with their experience the probability of continuing their work with certain organization is higher (Cnaan and Goldberg-Glen 1991; Finkelstein 2008). Therefore, we can say that satisfaction is a key element for volunteers retention (Silverberg et al. 2001) and there is a relationship between volunteers satisfaction and their length of stay (Vecina et al. 2010) since higher levels of satisfaction leads to higher periods of staying in a given organization (Omoto and Snyder 1995). Based on the evidence mentioned above, we assume that:

Hypothesis There is a positive relationship between volunteer satisfaction and intention to stay.

According to the literature, models that attempt to explain volunteers intention to stay incorporate some of the variables mentioned previously and their outcomes follow a functional approach (Vecina et al. 2010). The model used in our research is contiguous to the functional approach as it emphasizes the importance of motivation and satisfaction (Clary et al. 1998; Stukas et al. 2009). In this scenario, we propose the research model presented in Fig. 1, inspired in the Volunteer process model proposed by Omoto and Snyder (1995). This model considers volunteering as a process determined by a combination between motivations for volunteering and experiences of current volunteers (Omoto and Snyder 1995; Penner 2002). Thus, we adapted the previous model adding the variable "management factors," since literature highlights the lack of knowledge about volunteer management practices (Stamer et al. 2008) and because it is essential to understand the context influence on volunteers performance (Paúl et al. 1999). The set of hypotheses that we formulated are also shown in the figure.

\section{Methods}

Sample

We considered the set of volunteers that perform their activities in hospitals as one group. These volunteers had to belong to a NPO and have close contact with the final beneficiaries of the hospital, in this case patients and/or their familiars. Using data from INE (2001) and the National Health Department, we compiled a list of the 108 public hospitals in Portugal, spread throughout the country. We contacted all 


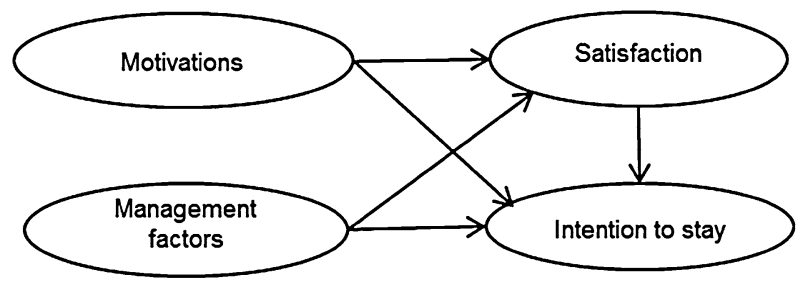

Fig. 1 Theoretical model

the hospitals by telephone and learned that 14 of them did not have volunteers. We did not get any information from 25 hospitals, leaving a total of 69 hospitals that we could identify as having volunteers. We use a multi-stage random sampling (Maroco 2003). We consider hospitals as groups and in order to have a representative sample we need to have 19 groups, so we present data from 19 different NPO's working in 19 hospitals. NPOs are very similar in their modus operandi and dimension. The participants belong to 19 organizations that work voluntarily with hospitals, supporting patients, and their families. In total, 304 volunteers participated in the survey. The volunteers were recruited through the organization, specifically through the volunteers' managers. Surveys were collected within 3 months of the original date of distribution (October of 2009). Each participant needed to return the survey to the volunteer manager and then all the surveys were collected from the organizations. Participants are predominantly woman (84\%) and have been working for the same organization for 7 years. Most of the volunteers are part-time and donate, on average, nearly $6 \mathrm{~h}$ per week to their organization. Table 1 shows data about civil status, age, education, and monthly income-most of the volunteers are married and are between 52 and 68 years old, have an income less than 2000 Euros and have a college degree.

\section{Measures and Procedures}

A survey instrument was prepared to measure volunteers' motivations, satisfaction, intention to stay, and management factors. To measure satisfaction, we used a combination of items (Chacón et al. 2007; Dávila and Chacón 2002; Silverberg et al. 2001; Stukas et al. 2009) which include questions related to satisfaction with motivations and management factors. The twenty-one items of this measure were scored using a seven-point Likert scale. We used the average of each group as indicators of the latent variable, "satisfaction." To measure the intention to stay, we used a combination of items (Arias 2008; Chacón et al. 2007; Cho et al. 2009; Meyer and Ohana 2009) that includes questions related to the volunteers' intention to stay and leave. The four items of this measure were scored using a seven-point Likert scale. We used the average of each group as indicators of the latent variable, "intention to stay." The management factors were measured in three groups, the first included questions related to recruitment and selection (Bradner 1995; Taylor et al. 2006), the second included questions related to training (Costa et al. 2006; Taylor et al. 2006), and the third had questions related to recognition/rewards 
Table 1 Demographic attributes

\begin{tabular}{lcclcr}
\hline Education & Frequency & $\%$ & Monthly income & Frequency & $\%$ \\
\hline Basic education & 67 & 22.0 & Up to 1,000€ & 68 & 22.4 \\
$9^{\circ}$ to $11^{\circ}$ year & 34 & 11.2 & ]1,000€-2,000€] & 73 & 24.0 \\
High school & 62 & 20.4 & ]2,000€-3,000€] & 30 & 9.9 \\
College degree & 76 & 25.0 & More than 3,000€ & 4 & 1.3 \\
Post-grad & 12 & 3.9 & Missing & 129 & 42.4 \\
Missing & 53 & 17.4 & Total & 304 & 100.0 \\
Total & 304 & 100.0 & & Frequency & $\%$ \\
\hline Civil state & Frequency & $\%$ & Age & 26 & 8.6 \\
\hline Single & 40 & 13.2 & $18-34$ & 38 & 12.5 \\
Married & 162 & 53.3 & $35-51$ & 145 & 47.7 \\
Divorced & 29 & 9.5 & $52-68$ & 60 & 19.7 \\
Widowed & 48 & 15.8 & $69-85$ & 35 & 11.5 \\
Missing & 25 & 8.2 & Missing & 304 & 100.0 \\
Total & 304 & 100.0 & Total & & \\
\hline
\end{tabular}

(Dávila and Chacón 2002). These three subscales were used as indicators for the latent variable, "management factors." The seventeen items of recruitment and selection and training were scored using a seven-point Likert scale, the thirteen items of recognition/reward were answered through "yes or no" options.

\section{Results}

It is very important to evaluate the quality of the collected data (Bollen 1989; Hair et al. 1998). We used an exploratory factor analysis to examine scales validity, considering as criteria eigenvalues greater than 1, factor loadings greater than 0.5 and values for Kaiser-Meyer-Olkin (KMO) greater than 0.7 (Hair et al. 1998). Then we checked scale reliability through Cronbach's alpha (Bollen 1989; Hair et al. 1998).

Given the previous criteria, we eliminated some of the satisfaction items. We got a good KMO (0.86), a good Cronbach alpha (0.87) and the total amount of variance explained by the solution is $64 \%$. We got a solution with three factors (intrinsic satisfaction, extrinsic satisfaction, and satisfaction with management factors). For the intention to stay, we got a reasonable KMO (0.69) a very good Cronbach alpha (0.93) and the total amount of variance explained by the solution is $89 \%$. We got a solution of one factor. Abandonment was measured by a single item calculated by adjusting the scales of the work mentioned above. Finally, for the management factors we did three factor analyses. For the recruitment and selection, we got a good KMO (0.88), a good Cronbach alpha (0.89), and the total amount of variance explained by the solution is $67 \%$. We got a solution with one factor. For training we 
eliminated one item, we got a very good KMO (0.91), a very good Cronbach alpha (0.92), and the total amount of variance explained by the solution is $61 \%$. We got a solution with one factor. For the recognition/reward we eliminated eight items, we got a reasonable KMO (0.76), a reasonable Cronbach alpha (0.71), and the total amount of variance explained by the solution is $48 \%$. We got a solution of one factor.

The measurement model was estimated in AMOS 17.0. We used the maximumlikelihood method (ML), this is a traditional method and widely used in structural equation analysis (Hair et al. 1998). In a general way, the method is robust and capable of producing reliable results when compared with other methods (Hair et al. 1998). In order to have comparative interpretations, estimated coefficients are standardized. Convergent and discriminant validity demonstrate construct validity and can be analyzed in Tables 2 and 3 (Appendices 1,2). The measures of goodness of fit of the model in the first instance showed that it was necessary to make some changes, since the model did not provide a good fit to the data. According to Marôco (2010), it is possible, with a small number of changes, to significantly improve the adjustment of the model. We can use the modification indices (Byrne 2010; Hair et al. 1998) accompanied by significant theoretical explanations (Marôco 2010). Therefore, using the modification indices and the work of some authors (Ferrari et al. 2007; Karr et al. 2006; Millette and Gagné 2008), we considered a new relationship between motivations and management factors and some errors. The new model shows an adjustment measurement that reveals a very good adaptation of the modified structure. Considering the measurement and structural model, estimated with maximum-likelihood estimation, we can say that the model fit the data well (Table 4). The measurement model exhibits a good overall fit $\left(\chi^{2}=114.5\right.$, root mean square error of approximation [RMSEA] $=0.078$, comparative fit index $[\mathrm{CFI}]=0.911$, goodness-of-fit index $[\mathrm{GFI}]=0.936$ ). All parameter estimates are reasonable and within their permissible ranges. All factor loadings are statistically significant.

Respecifying the model could be problematic, and one way of addressing this problem is "to employ a cross-validation strategy whereby the final model derived from the post hoc analyses is tested on a second independent sample from the sample population" (Byrne 2010, p. 258). We can see in Table 5 (Appendix 3) the invariance of the fixed weights in both groups. We can also see that tested parameters are operating equivalently across the groups, so we can conclude that the invariance of the measurement model between the two samples is demonstrated.

\section{Discussion}

The present study intends to understand volunteers' intention to stay in an organization, and therefore identified a set of hypothesis that supports this understanding. Upon analyzing the structural model in Fig. 2, we can see that there is a positive relation between motivations and satisfaction, between management factors and satisfaction, between satisfaction and intention to stay, and between 
motivations and management factors. What follows is a discussion of each of these relationships.

$\mathbf{H}_{1}$ There is a positive relationship between volunteers' motivation and satisfaction.

If the organization meets volunteers' motivations then the result will have a positive impact on their satisfaction. Development and learning and altruism are the main motivations of hospital volunteers (Table 6 in Appendix 4). The work in a hospital environment and the contact with patients and/or their families allows volunteers to precisely meet their expectations and have high levels of satisfaction, materializing the impact of motivations in satisfaction. In the research conducted by Tewksbury and Dabney (2004) with volunteers that carry out their activities in a prison we can also see high levels of satisfaction. Most volunteers were motivated by a strong sense of religious values and most of them are largely satisfied with their experience, meaning that their involvement with the organization and with the prisoners allows them to put their religious values into practice. The importance of understanding volunteers motivations is highlighted in several studies (Clary et al. 1998; Prouteau and Wolff 2008; Rhoden et al. 2009) although motivations may change over time and can cause fatigue, leading to the inevitable abandonment of the organization.

$\mathbf{H}_{3}$ There is a positive relationship between management factors (recruitment and selection, training and recognition/reward) and volunteer' satisfaction.

Satisfaction with management factors has a fairly high value (4.96-see Table 6 in Appendix 4), while confirming this hypothesis reinforces the idea of the management factors impact on the volunteers' satisfaction. If they are satisfied with the management factors then their overall satisfaction tends to be higher. Several authors (Cnaan and Cascio 1998; Millette and Gagné 2008; Willis 1991) recognize this relationship, stating that volunteers satisfaction will be influenced by good management practices. In our research, volunteers with high levels of education are those with lower satisfaction with management factors (Table 6 in Appendix 4), probably because of their greater knowledge about good management practices and, therefore, more demanding expectations regarding to these practices. In terms of recruitment and selection, NPOs in this research mainly use "word-of-mouth" and interviews. According to Blanchard (2006), this process must include a detailed analysis about what volunteers expect from a certain function. That is what appears to happen in these NPOs, since volunteers are satisfied with management factors. Considering the training variable, the NPOs in this study usually offer short initial training and many volunteers would like to have a continuous training program in order to update their work and find new solutions (Costa et al. 2006). A training program tailored to the volunteers and sector needs (Nassar-McMillan and Lambert 2003; Osborne 1996) can increase volunteer satisfaction since it demonstrates how important, needed, and appreciated they are (Shin and Kleiner 2003). It is also important to mention the specificities of hospital volunteers and that managers must be able to identify any difficulties that affect these volunteers, including stress and sadness associated with the specific environment (Blanchard 2006). Finally, an 


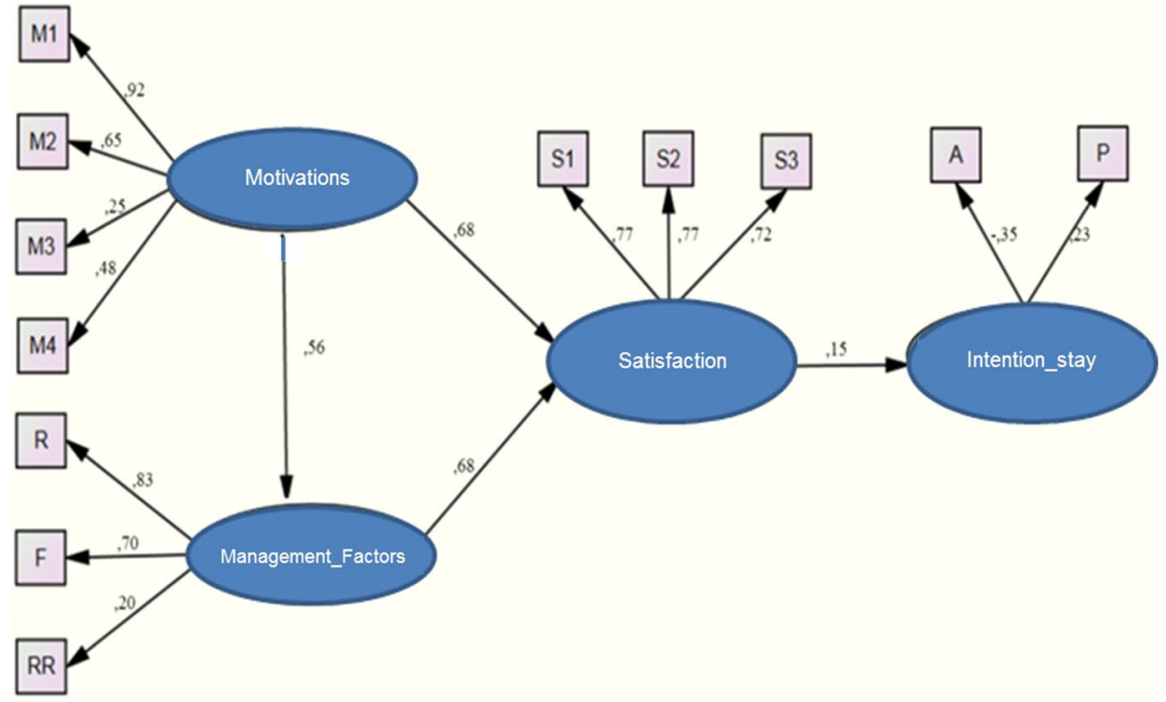

Fig. 2 Estimated structural model

appropriate system of recognition and rewards is a significant element for the satisfaction of volunteers, sometimes translated in the number of hours that volunteers devote to their organization and the number of years that volunteers remain in the organization (Block et al. 2010; Cnaan and Cascio 1998). In this study, volunteers dedicate about $6 \mathrm{~h}$ per week on average, which is above the national average (around 5 h) (Delicado et al. 2002) and consistent with Wymer (1999) who shows that hospital volunteers compared with those in other areas devote more hours to their organization. It is important to note that this variable can be regarded as an important indicator of volunteer dedication and satisfaction, since volunteers work because they want to and not because there is some kind of obligation (Gagné 2003). In our study most of the organizations do not use reward and recognition techniques, and although volunteers have expectations related to reward and recognition they are available to work without being rewarded, suggesting a simple, unaffected, and unpretentious attitude, and emphasizing the altruistic side of these volunteers.

$\mathbf{H}_{5}$ There is a positive relationship between volunteers' satisfaction and their intention to stay.

The validation of this hypothesis is consistent with previous work because the literature shows that satisfaction is a critical element in retaining volunteers (Costa et al. 2006; Cuskelly and Auld 2000b; Hager and Brudney 2004; Kim et al. 2007; Mesch et al. 1998; Watson and Abzug 2005). In our study, volunteers are satisfied so their intention of stay is high. The average length of stay of our volunteers is about 7 years, and the long-term dedication (over 5 years) is common in hospital volunteers (Delicado et al. 2002). Our data shows high retention rates and we 
identify small organizations with few volunteers but a large dependence on volunteer work, which reinforces the idea that satisfaction is high.

$\mathbf{H}_{6}$ There is a relationship between volunteers' motivations and management factors.

Volunteers' motivations cannot be understood without considering the interaction between organizational characteristics and individual motivations (Karr et al. 2006). According to Willis (1991), volunteers become more involved with the organization if the organization meets their interests and motivations. The same author states that volunteer motivations influence organization management, since an organization must provide some feedback to volunteers in order to retain them. For example, if the reasons for participation in a volunteer program are related to belonging, then the management factors (e.g., recruitment and selection) should consider this motivation in order to meet volunteers expectations (Ferrari et al. 2007).

\section{Theoretical and Practical Impacts}

In theoretical terms, inspired by the available literature, we developed a unique and representative research model. The model includes relationships between variables that have not been considered in previous researches and considers management factors which were jointly analyzed for the first time. The proposed model provided contributions at several levels, first allowed the identification of the antecedents of hospital volunteering intention to stay, presenting original combinations of variables.

Second, the model aggregates various management factors. Third, the model confirms the role of volunteer satisfaction as key to the intention to stay. Finally, helped increase knowledge regarding the intention of stay of hospital volunteers in Portugal, stressing the need of knowing the elements that influence this variable.

In practical terms, hospital volunteers can be an important workforce capable of contributing to the quality of the offered service (Bates 2009), making that patient can receive their care holistically, since volunteers complement the services offered by hospitals. We cannot forget that these volunteers work in an extremely delicate environment, are exposed to many diseases, sadness, and loss, and so they need support and preparation to face these different situations. Additionally, it can be stated that volunteers are increasingly aware to the need of a more "professional" volunteering (Howlett 2009), recognizing the importance and the need of adapting their performance because they know that their actions may influence organizations sustainability. Volunteers recognize the importance of having the right skills for the development of certain tasks and as such value and are more satisfied with the organizations that give them opportunities to work on their professional qualifications.

The result of our research allows NPOs to plan and establish appropriate and assertive management policies. Results show that motivations of hospital volunteers are mainly related with development and learning. Therefore, organizations must be 
aware of this feature during the recruitment and selection process. On the other hand, organizations can manage and assign tasks according to volunteers' profiles and motivations. Because of learning and development motivations, as well as intrinsic satisfaction, being so important to hospital volunteers, organizations must provide training adjusted to this reality, as suggested by Cheung et al. (2006). Give volunteers the opportunity to develop new skills and show them how their work helps NPOs to meet its mission, may be very prolific, similar to what (Millette and Gagné 2008) refer when they show that volunteer characteristics influence their motivations, satisfaction, and performance.

Another result of our research shows the role that management factors may have on volunteers' satisfaction. NPOs should know what management factors most influence volunteers satisfaction and how does this influence can be enhanced.

\section{Conclusion}

The main goal of this research was to understand volunteers' intention to stay. The results show a positive relationship between (a) motivation and satisfaction, (b) management factors and satisfaction, (c) satisfaction and intention to stay, and (d) motivation and management factors. These results present important outcomes that should be reflected in the way organizations act.

Hospital volunteers are mainly women, married and retired, with a mean age of 57 years and high levels of education. These volunteers spend about $6 \mathrm{~h}$ per week in their NPO and are, on average, in the same organization for about 7 years. This is important because "the field in which one operates is determined by a self-evident affinity with shared ideologies, religious convictions, and collective identities" (Hustinx and Lammertyn 2003, p. 177). In our research, volunteers work in hospitals providing support to patients and their families and have many similarities in regard to their socio-demographic characteristics as well as time devoted to the organization. The dedication of volunteers can increase the quality of life of many patients (Laverie and McDonald 2007) as they give a variety of support services that contribute to the additional comfort and happiness of patients, their families and visitors, they assist patients and reduce the anxieties of being vulnerable and alone (Handy and Srinivasan 2004). Hospital volunteers recognize the importance of having the right skills, expect that their NPOs diagnose their training needs and fit training programs to the needs of specific tasks. Most of the NPOs in this study have an undeveloped system of reward and recognition although volunteers are satisfied with what they get, highlighting volunteers' mode stand unpretentious attitudes regarding the donation of their time and work. NPOs should know which factors most influence volunteers' satisfaction in order to update or change the poorest ones. Volunteers are a very important group of stakeholders to NPOs, so organizations should establish specific strategies for this group, developing detailed activities to build, shape, and strengthen their relationship with these stakeholders.

In regard to limitations, we should mention that this research was restricted to the health area and to the opinion of only one stakeholder (volunteers). We assume volunteers' intention to stay as the actual behavior but that might not be true, and 
finally we should mention that there are other variables not considered here that might influence volunteers' intention to stay.

Acknowledgments The author João F. Proenca thanks Fundação para a Ciência e Tecnologia (FCT Portugal) for financial support to ADVANCE by the Multi-Year Funding Program for R\&D Units. The author Teresa Proença thanks Fundação para a Ciência e Tecnologia (FCT Portugal) for financial support to CEGE by the Multi-Year Funding Program for R\&D Units.

\section{Appendix 1: Discriminant validity}

See Table 2.

Table 2 Discriminant validity

\begin{tabular}{lccc}
\hline Factor/item & Standardized estimated coefficient (ML) & Statistic $t$ & $R^{2}$ \\
\hline Motivations (M) & & & \\
M1 & $\lambda_{1} 0.879$ & 12.139 & 0.772 \\
M2 & $\lambda_{2} 0.644$ & 8.423 & 0.415 \\
M3 & $\lambda_{3} 0.326$ & 3.037 & 0.251 \\
M4 & $\lambda_{4} 0.464$ & 6.224 & 0.215 \\
Management factors (MF) & $\lambda_{5} 0.735$ & 5.789 & \\
R & $\lambda_{6} 0.770$ & 6.597 & 0.541 \\
F & $\lambda_{7} 0.190$ & 2.397 & 0.593 \\
RR & $\lambda_{8} 0.733$ & & 0.036 \\
Satisfaction (S) & $\lambda_{9} 0.135$ & 2.893 & \\
S1 & $\lambda_{10} 0.711$ & 1.982 & 0.537 \\
S2 & & 8.849 & 0.118 \\
S3 & $\lambda_{11} 0.714$ & & 0.506 \\
Intention to stay (IS) & $\lambda_{12}-0.313$ & 1.979 & 0.510 \\
P & & -1.993 & 0.213 \\
A & & & \\
\hline
\end{tabular}

\section{Appendix 2: Convergent validity}

See Table 3. 
Table 3 Convergent validity-constructs fiability (respecified)

\begin{tabular}{|c|c|c|c|c|}
\hline $\begin{array}{l}\text { Factor/ } \\
\text { item }\end{array}$ & $\begin{array}{l}\text { Standardized estimated } \\
\text { coefficient }\end{array}$ & $\begin{array}{l}\text { Average variance } \\
\text { extracted (AVE) }\end{array}$ & $\begin{array}{l}\text { Construct } \\
\text { reliability (CR) }\end{array}$ & $\begin{array}{l}\text { Alpha de } \\
\text { Cronbach }\end{array}$ \\
\hline \multicolumn{5}{|c|}{ Motivations (M) } \\
\hline M1 & $\lambda_{1} 0.916$ & 0.593 & 0.719 & 0.624 \\
\hline M2 & $\lambda_{2} 0.650$ & & & \\
\hline M3 & $\lambda_{3} 0.251$ & & & \\
\hline M4 & $\lambda_{4} 0.477$ & & & \\
\hline \multicolumn{5}{|c|}{ Management factors (MF) } \\
\hline $\mathrm{R}$ & $\lambda_{5} 0.830$ & 0.538 & 0.688 & 0.604 \\
\hline $\mathrm{F}$ & $\lambda_{6} 0.702$ & & & \\
\hline RR & $\lambda_{7} 0.204$ & & & \\
\hline \multicolumn{5}{|c|}{ Satisfaction (S) } \\
\hline $\mathrm{S} 1$ & $\lambda_{8} 0.771$ & 0.539 & 0.663 & 0.601 \\
\hline $\mathrm{S} 2$ & $\lambda_{9} 0.772$ & & & \\
\hline S3 & $\lambda_{10} 0.720$ & & & \\
\hline \multicolumn{5}{|c|}{ Intention to stay (IS) } \\
\hline $\mathrm{P}$ & $\lambda_{11} 0.233$ & 0.343 & 0.205 & 0.187 \\
\hline A & $\lambda_{12}-0.351$ & & & \\
\hline
\end{tabular}

\section{Appendix 3: Cross-validation}

See Table 4.

Table 4 Estimated structural model respecification

\begin{tabular}{lllll}
\hline & Parameter & Estimative & $p$ value & Conclusion \\
\hline Main hypothesis & & & & \\
$\mathrm{H}_{1}:$ Motivations $\rightarrow$ satisfaction $(+)$ & $\gamma_{11}$ & 0.661 & 0.000 & Supported \\
$\mathrm{H}_{3}:$ Management factors $\rightarrow$ satisfaction $(+)$ & $\gamma_{12}$ & 0.675 & 0.000 & Supported \\
$\mathrm{H}_{5}:$ Satisfaction $\rightarrow$ intention of stay $(+)$ & $\beta_{21}$ & 0.534 & 0.000 & Supported \\
Other hypothesis & & & \\
$\mathrm{H}_{6}:$ Motivations $\rightarrow$ management factors & $\phi_{12}$ & 0.558 & 0.000 & Supported \\
Adjustments indices & & & \\
$\chi^{2}$ & 114.5 & & & \\
$\chi^{2} / g l$ & 2.86 & & & \\
CFI & 0.911 & & & \\
GFI & 0.936 & & & \\
TLI & 0.877 & & & \\
PGFI & 0.667 & & & \\
PCFI & 0.662 & & & \\
RMSEA & 0.078 & & \\
\hline
\end{tabular}




\section{Appendix 4: General averages}

See Table 5.

Table 5 Models comparison

\begin{tabular}{|c|c|c|c|c|c|c|c|}
\hline Model & $\mathrm{DF}$ & CMIN & $P$ & $\begin{array}{l}\text { NFI } \\
\Delta_{1}\end{array}$ & $\begin{array}{l}\text { IFI } \\
\Delta_{2}\end{array}$ & $\begin{array}{l}\text { RFI } \\
\rho_{1}\end{array}$ & $\begin{array}{l}\text { TLI } \\
\rho_{2}\end{array}$ \\
\hline \multicolumn{8}{|c|}{ Assuming model unconstrained to be correct } \\
\hline Measurement weights & 8 & 3,073 & 0.930 & 0.003 & 0.003 & -0.014 & -0.016 \\
\hline Structural covariances & 18 & 9,534 & 0.946 & 0.009 & 0.01 & -0.026 & -0.03 \\
\hline Measurement residuals & 30 & 32,895 & 0.327 & 0.03 & 0.033 & -0.023 & -0.026 \\
\hline \multicolumn{8}{|c|}{ Assuming model measurement weights to be correct } \\
\hline Structural covariances & 10 & 6,461 & 0.775 & 0.006 & 0.007 & -0.012 & -0.014 \\
\hline Measurement residuals & 22 & 29,822 & 0.123 & 0.027 & 0.03 & -0.009 & -0.01 \\
\hline \multicolumn{8}{|c|}{ Assuming model structural covariances to be correct } \\
\hline Measurement residuals & 12 & 23,361 & 0.025 & 0.021 & 0.024 & 0.003 & 0.003 \\
\hline
\end{tabular}

Table 6 General averages about gender, education, motivations, satisfaction, management factor, and intention to stay

\begin{tabular}{|c|c|c|c|c|c|c|c|c|c|c|c|c|}
\hline \multirow[t]{2}{*}{ Variables } & \multicolumn{4}{|c|}{ Motivations } & \multicolumn{3}{|c|}{ Satisfaction } & \multicolumn{3}{|c|}{$\begin{array}{l}\text { Management } \\
\text { factors }\end{array}$} & \multicolumn{2}{|c|}{$\begin{array}{l}\text { Intention to } \\
\text { stay }\end{array}$} \\
\hline & M1 & M2 & M3 & M4 & S1 & S2 & S3 & $\mathrm{R}$ & $\mathrm{T}$ & $\mathrm{RR}$ & $\mathrm{P}$ & A \\
\hline Average & 5.52 & 3.66 & 1.94 & 5.20 & 5.75 & 1.95 & 4.96 & 4.96 & 4.66 & 1.42 & 6.01 & 1.39 \\
\hline \multicolumn{13}{|l|}{ Gender } \\
\hline Masculine & 5.26 & 3.54 & 1.89 & 5.15 & 5.70 & 2.10 & 4.74 & 4.82 & 4.59 & 1.41 & 6.17 & 1.72 \\
\hline Feminine & 5.54 & 3.67 & 2.01 & 5.25 & 5.77 & 1.95 & 5.04 & 4.99 & 4.63 & 1.45 & 6.09 & 1.33 \\
\hline \multicolumn{13}{|l|}{ Education } \\
\hline Basic education & 5.68 & 4.08 & 1.89 & 5.13 & 5.86 & 1.92 & 5.14 & 5.13 & 4.78 & 1.60 & 6.15 & 1.28 \\
\hline $9^{\circ}$ to $11^{\circ}$ & 5.44 & 3.50 & 1.57 & 5.35 & 5.91 & 1.58 & 5.08 & 5.14 & 4.98 & 1.40 & 6.40 & 1.52 \\
\hline High school & 5.57 & 3.34 & 2.16 & 5.27 & 5.78 & 2.14 & 5.26 & 5.10 & 4.58 & 1.19 & 6.01 & 1.31 \\
\hline College degree & 5.40 & 3.46 & 2.21 & 5.33 & 5.65 & 2.05 & 4.70 & 4.90 & 4.39 & 1.43 & 6.01 & 1.31 \\
\hline Post-grad. & 5.55 & 3.32 & 1.68 & 5.71 & 5.73 & 1.64 & 4.60 & 5.54 & 4.93 & 2.41 & 6.64 & 1.28 \\
\hline
\end{tabular}

\section{References}

Akingbola, K. (2006). Strategy and HRM in nonprofit organizations: Evidence from Canada. International Journal of Human Resource Management, 17(10), 1707-1725.

Amos-Wilson, P. (1996). Management training in UK NGOs: A small survey. Journal of European Industrial Training, 20, 115-119.

Anderson, E., \& Cairncross, G. (2005). Understanding and managing volunteer motivation: Two regional tourism cases. Australian Journal on Volunteering, 10(2), 7-17. 
Arias, A. A. (2008). El Apoyo Social en la Predicción a Corto y Medio Plazo de la Permanencia del Voluntariado Socioasistencial. Psicothema, 20(1), 97-103.

Bates, D. (2009). The management of the role of the voluntary services manager. In R. Scott \& S. Howlett (Eds.), Volunteers in hospice and palliative care (2nd ed.). Oxford: Oxford University Press.

Bilhim, J. A. (2006). Teoria Organizacional (5th ed.). Lisboa: Instituto de Ciências Sociais e Políticas.

Blanchard, J. A. (2006). Hospital volunteers: A qualitative study of motivation. The International Journal of Volunteer Administration, 24(2), 31-40.

Block, E. M., Casarett, D. J., Spence, C., Gozalo, P., Connor, S. R., \& Teno, J. M. (2010). Got volunteers? Association of hospice use of volunteers with bereaved family members' overall rating of the quality of end-of-life care. Journal of Pain and Symptom Management, 39(3), 502-506.

Bollen, K. (1989). A structural equation with latent variables. New York: Wiley.

Bradner, J. H. (1995). Recruitment, orientation, and retention. In T. D. Connors (Ed.), The volunteer management handbook. New York: Wiley.

Brudney, J. L. (1990). Fostering volunteer programs in the public sector. San Francisco: Jossey-Bass Publishers.

Brudney, J. L. (2005). Designing and managing volunteer programs. In R. D. Herman \& Associates (Ed.), The Jossey-Bass handbook of nonprofit leadership \& management. San Francisco: Jossey-Bass.

Brudney, J. L., \& Kellough, J. E. (2000). Volunteers in state government: Involvement, management, and benefits. Nonprofit and Voluntary Sector Quarterly, 29(1), 111-130.

Brudney, J. L., \& Nezhina, T. G. (2005). What is old is new again: Achieving effectiveness with volunteer programs in Kazakhstan. Voluntas-International Journal of Voluntary and Nonprofit Organizations, 16(3), 293-308.

Bussell, H., \& Forbes, D. (2002). Understanding the volunteer market: The what, where, who and why of volunteering. International Journal of Nonprofit Volunteer Sector Marketing, 7(3), 244-257.

Byers, M. Lou, K., Volkema, R. J., \& Karmel, B. (1976). An empirical investigation of satisfaction with volunteer work in a community health center. In 36th Annual Meeting of the Academy Of Management (Vol. 76, pp. 483-487). Manhattan: Kansas State University.

Byrne, B. M. (2010). Structural equation modeling with AMOS (2nd ed.). New York: Routledge.

Cavalier, C. (2006). Adolescent volunteer. Marietta: Department of Education, Marietta College.

Chacón, F., Vecina, M. L., \& Dávila, M. C. (2007). The three-stage model of volunteers' duration of service. Social Behavior and Personality, 35(5), 627-642.

Chater, D. (2008). Coming in from the cold? The impact of the contract culture on voluntary sector homelessness agencies in England. Voluntary Sector Working Paper, 10, 1-37.

Cheung, F. Y., Tang, C. S., \& Yan, E. C. (2006). A study of older Chinese in Hong Kong. Journal of Social Service Research, 32(4), 193-209.

Cho, S., Johanson, M. M., \& Guchait, P. (2009). Employees intent to leave: A comparison of determinants of intent to leave versus intent to stay. International Journal of Hospitality Management, 28(3), 374-381.

Clary, R., Stukas, R. D., Snyder, A., Copeland, M., Haugen, J., \& Miene, P. (1998). Understanding and assessing the motivations of volunteers: A functional approach. Journal of Personality and Social Psychology, 74(6), 1516-1530.

Cnaan, R. A., \& Cascio, T. (1998). Perfomance and commitment: Issues in management of volunteers in human service organizations. Journal of Social Service Research, 24(3/4), 1-37.

Cnaan, R. A., \& Goldberg-Glen, R. S. (1991). Measuring motivation to volunteer in human services. Journal of Applied Behavioral Science, 27(3), 269-284.

Costa, C. A., Chalip, L., Green, B. C., \& Simes, C. (2006). Reconsidering the role of training in event volunteers' satisfaction. Sport Management Review, 9, 165-182.

Cunningham, I. (1999). Human resource management in the voluntary sector: Challenges and opportunities. Public Money \& Management, April-June, 19-25.

Cuskelly, G., \& Auld, C. (2000a). Volunteer management program-Recruiting volunteers. Brisbane: Australian Sports Commission.

Cuskelly, G., \& Auld, C. (2000b). Volunteer management program-The volunteer coordinator. Brisbane: Australian Sports Commission.

Cuskelly, G., Taylor, T., Hoye, R., \& Darcy, S. (2006). Volunteer management practices and volunteer retention: A human resource management approach. Sport Management Review, 9, 141-163.

Dartington, T. (1991). Professional management in voluntary organizations: Some cautionary notes. In J. Batsleer, C. Cornforth, \& R. Paton (Eds.), Issues in voluntary and non-profit management. Wokingham: Addison-Wesley Publishing Company. 
Dávila, M. C., \& Chacón, F. (2002). La Incidencia Diferencial de los Factores Psicosociales en Distintos Tipos de Voluntariado. Psicología Social: Universidad Complutense de Madrid, Madrid.

Delicado, A., de Almeida, A. N., \& Ferrão, J. (2002). Caracterização do Voluntariado em Portugal. Lisboa: Comissão Nacional para o Ano Internacional dos Voluntários.

Drucker, P. F. (1990). As Organizações sem Fins Lucrativos. Lisboa: Difusão Cultural.

Edwards, D. (2005). Understanding the organization of volunteers at visitor attractions. Sidney: College of Law and Business, University of Western Sydney.

Eikenberry, A. M., \& Kluver, J. D. (2004). The marketization of the nonprofit sector: Civil society at risk? Public Administration Review, 64(2), 132-140.

Esmond, J., \& Dunlop, P. (2004). Developing the volunteer motivation inventory to assess the underlying motivational drives of volunteers in Western Australia (pp. 1-81). CLAN WA Inc. Retrieved 07/01/ 2013 from http://www.morevolunteers.com/resources/MotivationFinalReport.pdf.

Farrell, J. M., Johnston, M. E., \& Twynam, G. D. (1998). Volunteer motivation, satisfaction, and management at an elite sporting competition. Journal of Sport Management, 12(4), 288-300.

Federman, B. (2009). Employee engagement. San Francisco: Jossey-Bass A Wiley.

Ferrari, J. R., Luhrs, T., \& Lyman, V. (2007). Eldercare volunteers and employees: Predicting caregiver experiences from service motives and sense of community. The Journal of Primary Prevention, 28(5), 467-479.

Ferreira, M. R., Proença, T., \& Proença, J. F. (2008). As Motivações no Trabalho Voluntário. Revista Portuguesa E Brasileira de Gestão, 7(3), 43-53.

Ferreira, M. R., Proença, T., \& Proença, J. (2012). Organisational influence on volunteer satisfaction and attitudes towards HRM practices: The case of hospital volunteers. International Review on Public and Nonprofit Marketing, 9(1), 27-42.

Finkelstein, M. A. (2008). Volunteer satisfaction and volunteer action: A functional approach. Social Behavior and Personality, 36(1), 9-18.

Frisch, M. B., \& Gerrard, M. (1981). Natural helping systems: A survey of red cross volunteers. American Journal of Community Psychology, 9(5), 567-579.

Gagné, M. (2003). The role of autonomy support and autonomy orientation in prosocial behavior engagement. Motivation and Emotion, 27(3), 199-223.

Galindo-Kuhn, R., \& Guzley, R. M. (2001). The volunteer satisfaction index: Construct definition, measurement, development, and validation. Journal of Social Service Research, 28(1), 45-68.

Gomes, D. R. (2009). Mundos Vividos: os Caminhos do Voluntariado Hospitalar. Sociologia: Universidade de Coimbra, Coimbra.

Hager, M., \& Brudney, J. (2004). Volunteer management practices and retention of volunteers. Volunteer management capacity study series. Washington: The Urban Institute.

Hager, M. A., \& Brudney, J. L. (2011). Volunteers: Nature versus nurture. Nonprofit Management \& Leadership, 22(2), 137-156.

Hair, J. F., Anderson, R. E., Tatham, R. L., \& Black, W. C. (1998). Multivariate data analysis (5th ed.). Englewood: Prentice Hall International.

Handy, F., \& Srinivasan, N. (2004). Valuing volunteers: An economic evaluation of the net benefits of hospital volunteers. Nonprofit and Voluntary Sector Quarterly, 33(1), 28-54.

Hartenian, L. S. (2007). Nonprofit agency dependence on direct service and indirect support volunteers. Nonprofit Management \& Leadership, 17(3), 319-334.

Henderson, K. A. (1981). Motivations and perceptions of volunteerism as a leisure activity. Journal of Leisure Research, 13(3), 208-218.

Hibbert, S., Piacentini, M., \& Dajani, H. Al. (2003). Understanding volunteer motivation for participation in a community-based food cooperative. International Journal of Nonprofit and Voluntary Sector Marketing, 8(1), 30-43.

Hidalgo, M. C., \& Moreno, P. (2009). Organizational socialization of volunteers: The effect on their intention to remain. Journal of Community Psychology, 37(5), 594-601.

Horton-Smith, D. (1981). Altruism, volunteers and volunteerism. Nonprofit and Voluntary Sector Quarterly, 10(1), 21-36.

Hotchkiss, R. B., Fottler, M. D., \& Unruh, L. (2009). Valuing volunteers. The impact of volunteerism on hospital performance. Health Care Management Review, 34(2), 119-128.

Howarth, E. (1976). Personality characteristics of volunteers. Psychological Reports, 38, 855-858.

Howlett, S. (2009). Setting the scene: The landscape of volunteering. In R. Scott \& S. Howlett (Eds.), Volunteers in hospice and palliative care (2nd ed.). Oxford: Oxford University Press. 
Huber, E. (2011). Adult volunteer retention in an after-school garden club setting: A case study. Manhattan: Department of Horticulture, Forestry and Recreation Resources College of Agriculture, Kansas State University.

Hustinx, L., \& Lammertyn, F. (2003). Collective and reflexive styles of volunteering: A sociological modernization perspective. Voluntas: International Journal of Voluntary and Nonprofit Organizations, 14(2), 167-187.

INE. (2001). Número de Hospitais por localização geográfica; Anual—INE, inquéritos aos Hospitais.

Karl, K. A., Peluchette, J. V., \& Hall, L. M. (2008). Give them something to smile about: A marketing strategy for recruiting and retaining volunteers. Journal of Nonprofit \& Public Sector Marketing, 20(1), 71-96.

Karr, L. B., Meijs, L. C. P. M., \& Lerner, M. J. (2006). Sustaining the motivations to volunteer in organizations. In D. Fetchenhauer, A. Flache, B. Buunk, \& S. Lindenberg (Eds.), Solidarity and prosocial behavior (pp. 157-172). Groningen: Springer.

Kemp, S. (2002). The hidden workforce: Volunteers' learning in the olympics. Journal of European Industrial Training, 26(2/3/4), 109-116.

Kim, M., Chelladurai, P., \& Trail, G. (2007). A model of volunteer retention in youth sport. Journal of Sport Management, 21, 151-171.

Kulik, L. (2007). Predicting responses to volunteering among adolescents in Israel: The contribution of personal and situational variables. Voluntas: International Journal of Voluntary and Nonprofit Organizations, 18, 35-54.

Latham, G. P. (2007). Work motivation. Thousand Oaks: Sage.

Latham, G. P., \& Pinder, C. C. (2005). Work motivation theory and research at the dawn of the twentyfirst century. Annual Reviews Psychology, 56, 485-516.

Laverie, D. A., \& McDonald, R. E. (2007). Volunteer dedication: Understanding the role of identity importance on participation frequency. Journal of Macromarketing, 27(3), 274-288.

Locke, E. A. (1976). Nature and causes of job satisfaction. In M. D. Dunnette (Ed.), Handbook of industrial and organizational psychology (pp. 1297-1349). Chicago: Rand McNally.

Lulewicz, S. J. (1995). Training and development of volunteers. In T. D. Connors (Ed.), The volunteer management handbook. New York: Wiley.

Luthans, F. (2011). Organizational behavior (12th ed.). New York: McGraw-Hill/Irwin.

Maroco, J. (2003). Análise Estatística (2nd ed.). Lisboa: Edições Sílabo.

Marôco, J. (2010). Análise de Equações Estruturais. Pêro Pinheiro: Edição em Português Publicado.

McBride, A. M., \& Lee, Y. (2012). Institutional predictors of volunteer retention: The case of AmeriCorps national service. Administration \& Society, 44(3), 343-366. doi:10.1177/0095399711 413729.

McCurley, S. (2005). Keeping the community involved. In R. D. Herman \& Associates (Ed.), The JosseyBass Handbook of nonprofit leadership \& management. San Francisco: Jossey-Bass.

Meier, S., \& Stutzer, A. (2004). Is volunteering rewarding in itself? IZA Discussion Paper, 1045, 1-32.

Mesch, D. J., Tschirhart, M., Perry, J. L., \& Lee, G. (1998). Altruists or egoists? Retention in stipended service. Nonprofit Management \& Leadership, 9(1), 3-21.

Meyer, M., \& Ohana, M. (2009). Intention to quit in social enterprises: The role of justice, LMX, job satisfaction and organizational commitment. In 24th Workshop on Strategic Human Resource Management, Brussels, Belgium.

Millette, V., \& Gagné, M. (2008). Designing volunteers' tasks to maximize motivation, satisfaction and performance: The impact of job characteristics on volunteer engagement. Motivation and Emotion, $32,11-22$.

Monroe, K. R. (1996). The heart of altruism. Princeton University Press.

Musick, M. A., \& Wilson, J. (2008). Volunteers-A social profile. Philanthropic and nonprofit studies. Bloomington: Indiana University Press.

Nassar-McMillan, S. C., \& Lambert, R. (2003). The relationship between volunteers' work behaviors and background and preparation variables. Journal of Adult Development, 10(2), 89-97.

Nogueira-Martins, M. C. F., Bersusa, A. A. S., \& Siqueira, S. R. (2010). Humanização e voluntariado: estudo qualitativo em hospitais públicos. Revista de Saúde Pública, 44(5), 942-949.

Nunes, F., Reto, L., \& Carneiro, M. (2001). O Terceiro Sector em Portugal: Delimitação, Caracterização e Potencialidades. Lisboa: INSCOOP.

Omoto, A. M., \& Snyder, M. (1993). Aids volunteers and their motivations: Theoretical issues and practical concerns. Nonprofit Management and Leadership, 4(2), 157-176. 
Omoto, A. M., \& Snyder, M. (1995). Sustained helping without obligation: Motivation, longevity of service, and perceived attitude change among AIDS volunteers. Journal of Personality and Social Psychology, 68(4), 671-686.

Osborne, S. P. (1996). What kind of training does the voluntary sector need. In D. Billis \& M. Harris (Eds.), Voluntary agencies. Basingstoke: Macmillan.

Paúl, C., Martin, I., \& Roseira, L. (1999). Comunidade e Saúde. Porto: Edições Afrontamento.

Peach, E. B., \& Murrell, K. L. (1995). Reward and recognition systems for volunteers. In T. D. Connors (Ed.), The volunteer management handbook. New York: Wiley.

Pedro, J. R. (2010). Voluntariado no Domínio da Gerontologia: Estudo de Caso da Liga dos Amigos do Hospital de Santo António. Gerontologia Social. Porto: Instituto Superior de Serviço Social.

Penner, L. A. (2002). Dispositional and organizacional influences on sustained volunteerism: An interactionist perspective. Journal of Social Issues, 58(3), 447-467.

Phillips, M. (1982). Motivation and expectation in successful volunteerism. Nonprofit and Voluntary Sector Quarterly, 11, 118-125.

Prouteau, L., \& Wolff, F.-C. (2008). On the relational motive for volunteer work. Journal of Economic Psychology, 29(3), 314-335.

Pynes, J. E. (2009). Human Resources Management for Public and Nonprofit Organizations (3rd ed.). San Francisco: Wiley.

Qureshi, H., Davies, B., \& Challis, D. (1979). Motivations and rewards of volunteers and informal care givers. Nonprofit and Voluntary Sector Quarterly, 8(1-2), 47-55.

Raman, P., \& Pashupati, K. (2002). Turning good citizens into even better ones: The impact of program characteristics and motivations on service learning outcomes. Journal of Nonprofit \& Public Sector Marketing, 10(2), 187-206.

Randle, M., \& Dolnicar, S. (2009). Not just any volunteers: Segmenting the market to attract the high contributors. Journal of Nonprofit \& Public Sector Marketing, 21(3), 271-282.

Rhoden, S., Ineson, E. M., \& Ralston, R. (2009). Volunteer motivation in heritage railways: A study of the West Somerset Railway volunteers. Journal of Heritage Tourism, 4(1), 19-36.

Ridder, H.-G., \& McCandless, A. (2010). Influences on the architecture of human resource management in nonprofit organizations: An analytical framework. Nonprofit and Voluntary Sector Quarterly, 39(1), 124-141.

Ryan, R. M., \& Deci, E. L. (2000). Self-determination theory and the facilitation of intrinsic motivation, social development, and well-being. American Psychologist, 55(1), 68-78.

Schervish, P. G. (1993). The dependent variable of the independent sector: The definition and measurement of giving and volunteering. Voluntas: International Journal of Voluntary and Nonprofit Organizations, 4(2), 223-232.

Shin, S., \& Kleiner, B. H. (2003). How to manage unpaid volunteers in organisations. Management Research News, 26(2), 63-71.

Silverberg, K. E., Marshall, E. K., \& Ellis, G. D. (2001). Measuring job satisfaction of volunteers in public parks and recreation. Journal of Park and Recreation Administration, 19(1), 79-92.

Smith, D. B., \& Schneider, B. (2004). Where we've been and where we're going: some conclusions regarding personality and organizations. In Personality and organizations. Mahwah: Lawrence Erlbaum Associates.

Soupourmas, F., \& Ironmonger, D. (2001). Giving time: The economic and social value of volunteering in Victoria. Victoria: Department of Human Services.

Stamer, D., Lerdall, K., \& Guo, C. (2008). Managing heritage volunteers: An exploratory study of volunteers programmes in art museums worldwide. Journal of Heritage Tourism, 3(3), 203-214.

Starnes, B. J., \& Wymer, W. W. (2001). Conceptual foundations and practical guidelines for retaining volunteers who serve in local nonprofit organizations. In D. R. Self, W. W. Wymer, \& T. K. Henley (Eds.), Marketing communications for local nonprofit organizations: Targets and tools. Binghamton: Haworth Press.

Stukas, A. A., Worth, K. A., Clary, E. G., \& Snyder, M. (2009). The matching of motivations to affordances in the volunteer environment. Nonprofit and Voluntary Sector Quarterly, 38(1), 5-28.

Tapp, J. T., \& Spanier, D. (1973). Personal characteristics of volunteer phone counselors. Journal of Consulting and Clinical Psychology, 41(2), 245-250.

Taylor, T., Darcy, S., Hoye, R., \& Cuskelly, G. (2006). Using psychological contract theory to explore issues in effective volunteer management. European Sport Management Quarterly, 6(2), 123-147.

Tewksbury, R., \& Dabney, D. (2004). Prison volunteers. Journal of Offender Rehabilitation, 40(1/2), $173-183$. 
Torrington, D., Hall, L., \& Taylor, S. (2002). Human resource management (5th ed.). Harlow: Prentice Hall.

Trogdon, S. E. (2005). A study of parks and recreation citizen board members in North Carolina and their motivation for participation. Raleigh: North Carolina State University.

Vantilborgh, T., Bidee, J., Pepermans, R., Willems, J., Huybrechts, G., \& Jegers, M. (2011). A new deal for NPO governance and management: Implications for volunteers using psychological contract theory. Voluntas: International Journal of Voluntary and Nonprofit Organizations, 22(4), 639-657.

Vecina, M. L., Chacón, F., \& Sueiro, M. J. (2010). Differences and similarities among volunteers who drop out during the first year and volunteers who continue after eight years. The Spanish Journal of Psychology, 13(1), 343-352.

Warner, S., Newland, B. L., \& Green, B. C. (2011). More than motivation: Reconsidering volunteer management tools. Journal of Sport Management, 25(5), 391-407.

Watson, M. R., \& Abzug, R. (2005). Finding the ones you want, keeping the ones you find. In R. D. Herman \& Associates (Eds.), The Jossey-Bass handbook of nonprofit leadership \& management. San Francisco: Jossey-Bass.

Willis, E. (1991). Managing volunteers. In J. Batsleer, C. Cornforth, \& R. Paton (Eds.), Issues in voluntary and non-profit management. Wokingham: Addison-Wesley Publishing Company.

Wilson, J. (2000). Volunteering. Annual Review of Sociology, 26(1), 215-240.

Wymer, W. W. (1999). Hospital volunteers as customers: Understanding their motives, how they differ from other volunteers, and correlates of volunteer intensity. Journal of Nonprofit \& Public Sector Marketing, 6(2/3), 51-76. 